Fous

Folia Malacol. 27(4): 307-313

\title{
CEPAEA NEMORALIS (L.) ON GOTLAND, SWEDEN: SPREAD AND VARIATION
}

\author{
ROBERT A. D. CAMERON ${ }^{1,2}$, TED VON PROSCHWITZ ${ }^{3}$
}

\begin{abstract}
${ }^{1}$ Department of Animal and Plant Sciences, University of Sheffield, Sheffield S10 2TN, United Kingdom ${ }^{2}$ Department of Zoology, the Natural History Museum, London SW7 5BD, United Kingdom (e-mail: r.cameron@sheffield.ac.uk) ${ }^{3}$ Göteborg Natural History Museum, PO Box 7283, SE-40235 Göteborg, Sweden
\end{abstract}

ABSTRACT: Cepaea nemoralis is an introduced species on Gotland. The first records, from the capital city of Visby, date from the 1860's. Known initially from only three localities, it remained uncommon and restricted through the first half of the 20th century. Sampling from 1992 onwards, however, revealed that the species had spread into many sites in and near the city and also to Ardre on the opposite side of the island. Populations from both the 19th century and from the last 27 years were polymorphic for both colour and banding patterns. There is no evidence of general and consistent change in morph frequencies over time. While the frequencies of various banding patterns vary in a manner attributable to genetic drift and founder effect, variation in the frequencies of colour morphs is more restricted, suggesting that selection may also be involved. The data here provide a baseline for monitoring future changes.

KEY WORDS: introduced species, Cepaea nemoralis, shell polymorphism, Gotland, Sweden

\section{INTRODUCTION}

The land snail Cepaea nemoralis (L.) is famous for its shell colour and banding polymorphism (JONES et al. 1977, COOK 1998). The genetics of much of the variation is known, though that of minor variation in number of bands and of fusions among them remains undetermined (summary in JONES et al. 1977). This knowledge has made it a model organism for studying evolutionary processes both over time and among contemporary populations (OŻGO 2008, 2012, COOK 2017). There are many cases in which natural selection for crypsis or in response to climate accounts for some variation in both time and space (OŻGO 2008, ROSIN et al. 2011, SILVERTOWN et al. 2011, CoOK 2017). Founder effects and genetic drift, however, are also involved, especially where there is evidence of past bottlenecks (CAMERON \& DILLON 1984) and where C. nemoralis has recently colonised previously unoccupied areas, usually assisted by accidental transport by humans (CAMERON et al. 2009).There are many such areas, both within its assumed natural range and in places where it has been introduced beyond it, especially in eastern and northern Europe (OŻGO 2005, PELTANOVÁ et al. 2012, CAMERON et al. 2014, GHEOCA 2018, OżGO et al. 2019). The species flourishes in anthropogenic habitats, and is mostly confined to these habitats in such recently colonised regions.

In Sweden, C. nemoralis is an introduced species. While it may have been established for several centuries in the extreme south (Skåne) of the country, introductions elsewhere appear to originate from the mid 19th century at the earliest. In Göteborg (MALM 1851, CAMERON et al. 2014), the species remained very restricted for many decades thereafter, but spread rapidly in the last 30 years, a pattern repeated in many parts of Sweden south of $58^{\circ} \mathrm{N}$. The island of Gotland, in the Baltic Sea, lies approximately $370 \mathrm{~km}$ east of Göteborg. As in that city, the first records of C. nemoralis come from the 19th century (LINDSTRÖM 1868), within the city of Visby. The only subsequent published account of $C$. nemoralis on Gotland is that of VON PROSCHWITZ (2014). 
There are, however, numerous samples of $C$. nemoralis from Gotland in Swedish museums. In this study we set out to document the spread of $C$. nemoralis on the island, and to see if the patterns of variation in time and space matched those recorded elsewhere where the species had spread recently. A secondary aim was to establish a baseline for future studies.

\section{AREA STUDIED}

Gotland, an island in the Baltic Sea (centred on $18.5^{\circ} \mathrm{E}, 57.5^{\circ} \mathrm{N}$ ) has an area of $2,994 \mathrm{~km}^{2}$. The bedrocks are mainly Silurian limestones. The climate is slightly warmer and drier than that of Göteborg, with a mean January temperature of $-0.6^{\circ}$ (versus $\left.-0.5^{\circ}\right)$ a mean July temperature of $17.9^{\circ}$ (versus $16.8^{\circ}$ ) and rainfall of $525 \mathrm{~mm}$ year ${ }^{-1}$ (versus $875 \mathrm{~mm}$

year $\left.^{-1}\right)$. Autumns are milder, but winter cold persists for longer. The main city and port is Visby. It has a population of ca. 24,000 and an area of $12.4 \mathrm{~km}^{2}$. Populations of $C$. nemoralis have been found only in and near Visby, and at Ardre, Ljugarn $\left(18.70^{\circ} \mathrm{E}\right.$, $57.32^{\circ}$ N, Fig. 1).
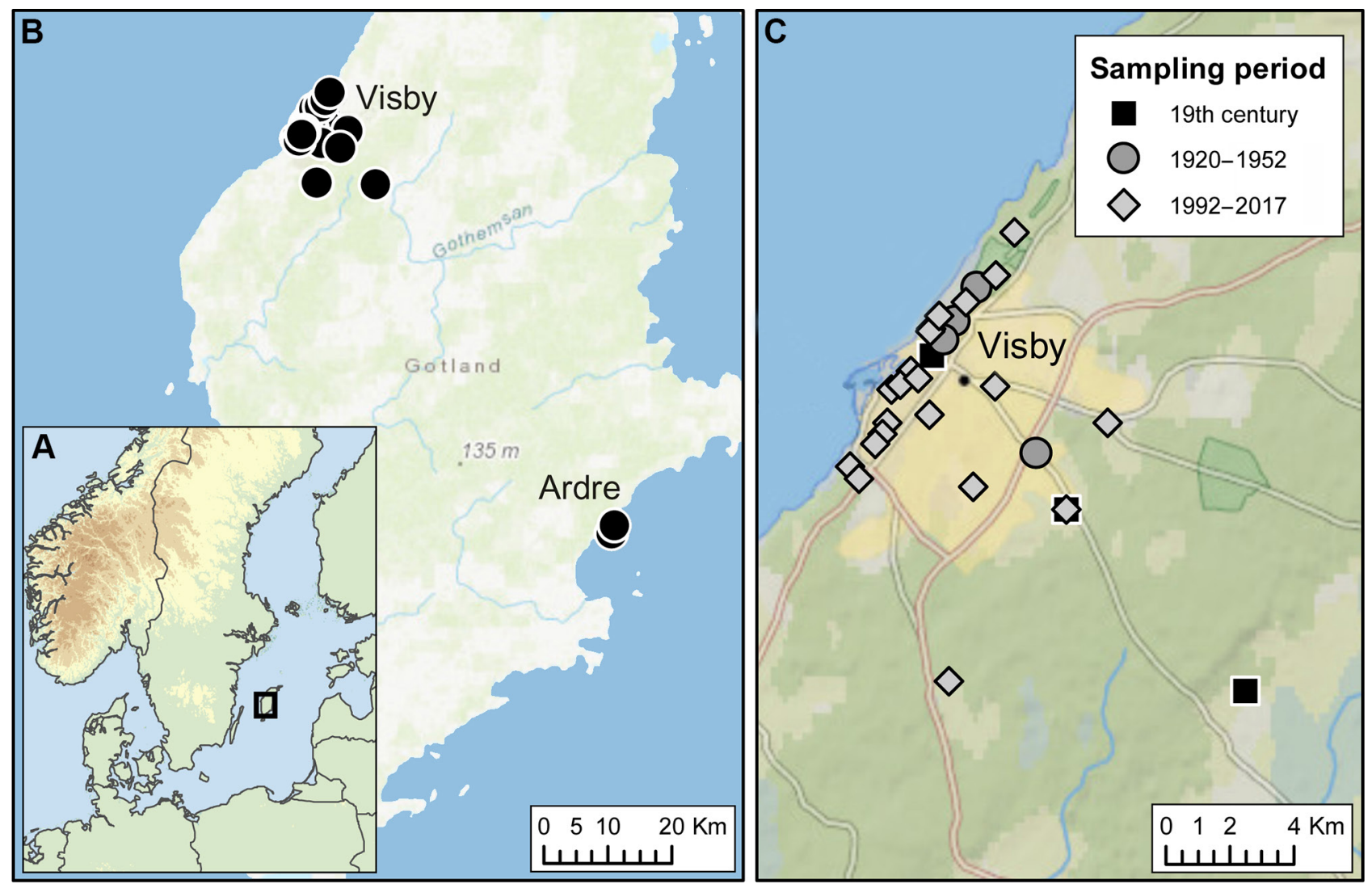

Fig. 1. Study area: A - the position of Gotland; B - central Gotland showing the location of samples of Cepaea nemoralis; $\mathrm{C}$ - the Visby region with sites for $\mathrm{C}$. nemoralis coded by age

\section{MATERIAL AND METHODS}

All the samples of $C$. nemoralis used for analysis are held in the Natural History Museums of Göteborg, Uppsala or Stockholm (Appendix 1). In addition, we have the data from faunistic surveys by H. LOHMANDER (see: Appendix 1), who sampled 1,616 sites on the island between 1921 and 1943 . These note presence or absence only. These unpublished records are held in the Mollusca database of the Göteborg Natural History Museum. Early sam- ples in which polymorphism could be scored were made by several people, but all those from 1998 onwards were made by T. VON PROSCHWITZ, who also scored the variation in all samples. The earliest sample (1864) was made near the centre of Visby, while two samples from another locality (Skrubbs Lot, then on the outskirts of the city) were made in 1866 and 1868. Two further samples from a third site at Follingbo (Rosendal) date from the 1860's and 1875. 
Scoring of colour and banding morphs followed the system used by JONES et al. (1977) with a full tally of bands present and the extent of fusions among them. Full details are available from the Natural History Museum of Göteborg. Here we have used the standard categories of yellow, pink and brown for shell colour; for banding, we have used four standard categories of unbanded (00000), mid-banded (00300), trifasciate (00345) and many-banded (12345), with minor variants ascribed to the most appropriate category. Thus, for example, 00045 shells were allocated to the trifasciate class, and 10345 to the many-banded class. We have not considered the occurrence of fused bands as information about this is often absent from other studies, and is not always presented in a standard manner.

For analysis, only samples containing 10 or more scoreable shells were used, most of which concern the samples made since 1992. We did not attempt to classify habitats by shading; they were all from rather heterogeneous anthropogenic sites. Frequencies of the colour morphs and of unbanded shells were calculated relative to the whole sample; for midbanded the frequencies are those within the banded shells; for trifasciate they are those within shells with more than one band, reflecting the dominance hierarchy at these loci (JONES et al. 1977). We used a modified version of $\mathrm{F}_{\mathrm{ST}}$ (WEIR \& COCKERHAM 1984) as a measure of variation among samples; it was corrected for sampling error and used morph- rather than allele frequencies, following CAMERON et al. (2009). Given the small number of samples and the small area from which most of them are drawn, we have not attempted formal spatial analysis as in CAMERON et al. (2009).

\section{RESULTS}

\section{SITE DISTRIBUTION AND VARIATION OVER TIME}

The Appendix 1 gives details of the location and composition of all samples used. With respect to shell colour, only a single brown shell was found; all other major morphs were found in larger numbers. Figure 1 shows their distribution within the sampling area, grouped by the age of the sample. Of the three 19th century sites, two were sampled on more than one occasion within a few years (Table 1). For Skrubbs Lot, while we cannot be sure that exactly the same place was searched on each occasion, there is no significant difference in the proportion of yellow and pink shells between them, or in the proportion of mid-banded shells among those within the banded class. While the earlier and smaller sample contains no unbanded or trifasciate shells, the differences between them scarcely reach the level of statistical significance.

Skrubbs Lot was sampled again in 2017. The area had been developed, but retained waste ground. While the site sampled will differ in many ways from that sampled in the 1860's, differences in morph frequencies are modest; relative to the larger and later (1868) sample, unbanded shells have again increased in frequency, as have trifasciate shells, while mid-banded shells have decreased.

At Follingbo, the two small samples have simply been combined. This site, rather isolated relative to the remainder in or near Visby, has not been resampled. It differs little from that at Skrubbs Lot, but samples from both have lower proportions of both unbanded and mid-banded shells than from the third 19 th century site for which only "Visby" is available as a location.

Aside from these museum samples, there is a list, with some numbers, provided by LINDSTRÖM (1868) for Visby as a whole. Because some numbers are missing, it is impossible to estimate morph frequencies, but we can draw the conclusion that unbanded shells were very rare, that the balance of yellow and pink shells was roughly as it is in the accurately located samples, but that the frequencies of mid-banded shells was far greater, constituting more than $80 \%$ of enumerated shells.

Only four samples from museums can be found from the period 1875-1991 (Fig. 1, Appendix 1). Three of these, made by H. LOHMANDER in the 1920's

Table 1. The frequencies of major morphs in 19th century samples from Visby, together with that from Skrubbs Lot in 2017. The frequencies of midbanded and trifasciate shells are expressed relative to the number of banded shells in which the character is visible (see text)

\begin{tabular}{lccccc}
\hline & Follingbo & "Visby" & Skrubbs & Skrubbs & Skrubbs \\
& 1860's-1875 & 1864 & 1866 & 1868 & 2017 \\
\hline Yellow & $55 \%$ & $52 \%$ & $52 \%$ & $48 \%$ & $54 \%$ \\
Unbanded & $4 \%$ & $26 \%$ & $0 \%$ & $6 \%$ & $15 \%$ \\
Midbanded & $43 \%$ & $65 \%$ & $48 \%$ & $46 \%$ & $29 \%$ \\
Trifasciate & $25 \%$ & $0 \%$ & $0 \%$ & $14 \%$ & $22 \%$ \\
Sample size & 22 & 27 & 54 & 131 & 157 \\
\hline
\end{tabular}


Table 2. The mean, median and range of morph frequencies (\%) among 21 samples from around Visby, with the corrected estimate of $\mathrm{F}_{\mathrm{ST}}$ for each. The frequency of each morph from the single sample from Ardre is shown in the right-hand column

\begin{tabular}{lrcrcc}
\hline & mean & median & range & $\mathrm{F}_{\text {ST }}$ & Ardre \\
\hline Yellow & 54.6 & 54.5 & $30.0-76.1$ & 0.037 & 68.4 \\
Unbanded & 29.6 & 18.2 & $0-81.8$ & 0.271 & 0 \\
Midbanded & 40.3 & 48.3 & $0-71.4$ & 0.249 & 0 \\
Trifasciate & 9.3 & 0 & $0-44.0$ & 0.207 & 68.4 \\
\hline
\end{tabular}

(Appendix 1) and all within the city, consist of single shells retained to indicate presence. LOHMANDER sampled extensively across the island, and these represent the only records of $C$. nemoralis. One later sample (1951) contains seven shells. Variation in samples made from 1992 onwards is considered further below. Means, medians and ranges of morph frequencies in these samples do not indicate any consistent changes relative to the 19th century (Table 2).

\section{LATE 20TH AND 21ST CENTURY SAMPLES}

In total, samples of 10 or more shells were available from 21 sites in the vicinity of Visby, and a further sample was available from Ardre (Fig. 1). Table 2 shows the means, medians and ranges of morph frequencies for the Visby samples, together with estimates of $\mathrm{F}_{\mathrm{ST}}$ based on morph frequencies and corrected for sampling error. All populations sampled retain polymorphism for shell colour, and the $\mathrm{F}_{\mathrm{ST}}$ value is remarkably low. The range of morph frequencies is greater, and $\mathrm{F}_{\mathrm{ST}}$ values greater for all the banding morph frequencies. There are some samples monomorphic at each locus. The isolated sample from Ardre has morph frequencies at or near the extremes of the range at Visby, and it exceeds it in the case of trifasciate (00345). There is no evidence of a consistent pattern of linkage disequilibrium between colour and banding loci: out of 20 samples in which unbanded is present, it is in excess in yellow in ten cases, nine in pink and in one it is equal.

\section{DISCUSSION}

The populations of $C$. nemoralis recorded on Gotland are the product of 19th century introductions with possible later additions. Unlike the cases of Göteborg (CAMERON et al. 2014) or Sibiu, Romania (for C. hortensis Müller, 1774) (GHEOCA et al. 2019), an actual introduction is not documented, but the earliest record dates to 1864 . As in these other cases, an initial introduction appears to have survived with only limited expansion until the last decades of the 20th century, a conclusion reinforced by the island-wide surveys of LOHMANDER in the first

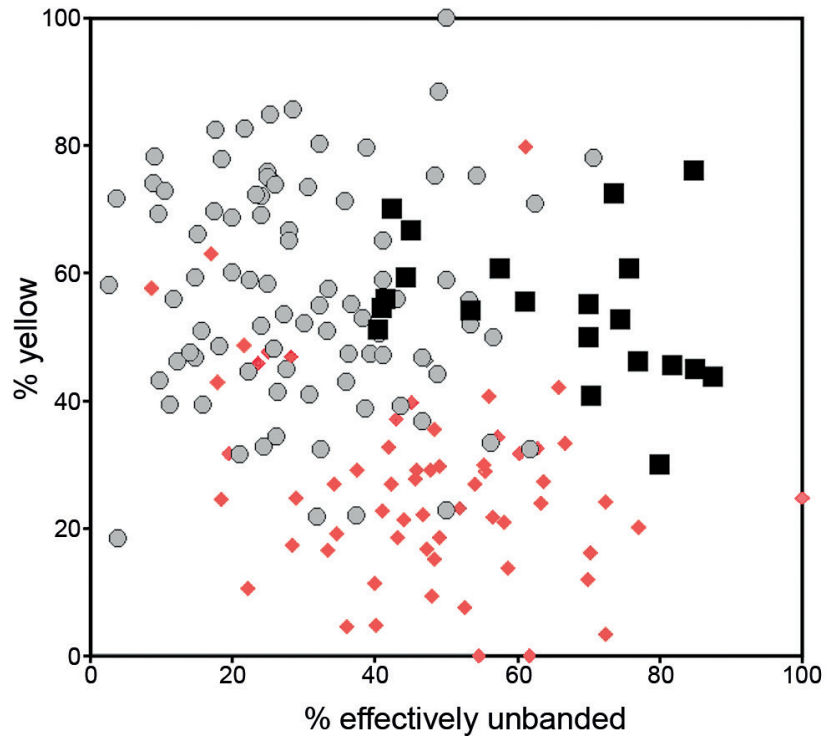

Fig. 2. The Cain and Sheppard diagram (COOK 2008). Effectively unbanded includes all shells in which the two upper bands are missing. The modern samples from Gotland are shown as large black squares. For comparison, the scatter of hedgerow samples (light grey circles) and of woodland samples (red diamonds) are shown from an area of ca. 5,000 $\mathrm{km}^{2}$ in central England where variation with habitat is strong. The data are extracted from the Evolution Megalab database (SILVERTOWN et al. 2011)

Given the small number of samples available, a quantitative analysis of geographical pattern has not been carried out. The greatest distance between sample sites around Visby is $8 \mathrm{~km}$. There are no significant relationships with either latitude or longitude, and samples close to one another often differ considerably. While we lack data to test for the effect of shade, a Cain and Sheppard diagram (Fig. 2) shows a scatter conforming to expectation in open habitats with regard to shell colour, but not for banding, where there is a higher proportion of effectively unbanded shells than in areas where variation with habitat is strong.

part of that century. Some caution is required in the case of Gotland, as LINDSTRÖM (1868) was able to record the presence of many hundreds of $C$. nemoralis in Visby, but without further details as to localities. At Burlington, New Jersey, USA, an introduction of C. nemoralis from England in 1857 was followed first by rapid expansion and large populations that later declined to near extinction (ÖRSTAN \& CAMERON 2015). Certainly, by the 1920 's, C. nemoralis appears to have been restricted to a few urban localities on Gotland. 
The pattern of late 20th century spread has been recorded in several urban areas (CAMERON et al. 2009, 2011, 2014, POKRYSZKO et al. 2012; for C. hortensis, SVERLOVA 2002). A more general advance northwards in Sweden has occurred at the same time (T. VON PROSCHWITZ, unpublished data). While climate change, with milder winters, may be implicated in this apparent release from constraint, factors such as decline in pollution and increased speed and volume of movement of horticultural goods may also be involved (CAMERON et al. 2009). Gotland is unique in one respect, having naturally calcium-rich soils derived from the limestone bedrock. It has not suffered from heavy pollution, which would anyway be buffered by these soils. Nevertheless, the pattern of spread seems similar to that recorded elsewhere.

The patterns of variation in the shell polymorphism show features in common with other areas in which there has been a rapid expansion in occupied sites. For banding morphs (but not for colour, see below), the range of frequencies is great and values of $\mathrm{F}_{\mathrm{ST}}$ are high relative to those found in areas where populations have been in existence for centuries (CAMERON et al. 2009). While there are too few samples to undertake a quantitative analysis, there appears to be no geographical structure in the variation, and differences can be attributed to founder effects and genetic drift in small and isolated populations. It is notable that frequencies in the sample from Ardre, well isolated from the remainder, are at or beyond the extremes of variation at Visby. It is possible, given that LINDSTRÖM (1868) appears to have recorded very high frequencies of midbanded shells, that this morph has declined in frequency, but localised 19th century records scarcely differ from the mean or median of modern samples.

This explanation, however, has a major difficulty. The range of variation in the frequency of shell colour morphs is restricted, and the value of $\mathrm{F}_{\mathrm{ST}}$ is very low even in comparison with values obtained from regions with long-standing and stable populations where natural selection related to habitat is clear and unambiguous (CAMERON et al. 2009). The mean frequency of yellow shells appears not to have changed since the 19th century. There is a marked contrast with the situation in Göteborg, where there is a substantial decline from frequencies of ca. $90 \%$ or more of yellow shells up to the 1980's followed by a decline to a mean less than $40 \%$ in the 21 st century. While scoring of colour in old samples can be problematic, both sets were scored by the same worker (T. VON PROSCHWITZ). Further, the $\mathrm{F}_{S T}$ value for yellow shell frequencies in Göteborg (0.212) is substantially greater than that for Visby (0.037) (CAMERON et al. 2014).

While such a difference with banding morphs might suggest a very strong selective force acting on colour alone, other explanations relating to different sources of initial colonisers are possible. Here, we note the discrepancy; the number of samples and the area covered are limited, and our data are best regarded as a baseline against which later samples can be compared. C. nemoralis continues to spread in Sweden, and Gotland is unlikely to be an exception.

\section{ACKNOWLEDGEMENTS}

We thank Michal and VerONIKA HORSÁK for composing the maps of Figure 1.

\section{REFERENCES}

Cameron R. A. D., Cox R. J., von Proschwitz T., HORSÁK M. 2014. Cepaea nemoralis (L.) in Göteborg, S.W. Sweden: variation in a recent urban invader. Folia Malacologica 22: 169-182. https://doi.org/10.12657/ folmal.022.016

CAmeron R. A. D., Dillon P. 1984. Habitat stability, population histories and patterns of variation in Cepaea. Malacologia 25: 271-290.

CAmeron R. A. D., OżGo M., Horsák M., BoguCKi Z. 2011. At the north-eastern extremity: variation in Cepaea nemoralis (L) around Gdańsk, northern Poland. Biologia 66: 1097-1113. https://doi.org/10.2478/ s11756-011-0128-9

CAmeron R. A. D., Pokryszko B. M., Horsák M. 2009. Contrasting patterns of variation in urban populations of Cepaea (Gastropoda: Pulmonata): a tale of two cities. Biological Journal of Linnean Society 97: 27-39. https://doi.org/10.1111/j.1095-8312.2008.01187.x

CoOK L. M. 1998. A two-stage model for Cepaea polymorphism. Philosophical Transactions of Royal Society B Biological Sciences 353: 1577-1593. https://doi. org/10.1098/rstb.1998.0311

CoOK L. M. 2008. Variation with habitat in Cepaea nemoralis: the Cain \& Sheppard diagram. Journal of Molluscan Studies 74: 239-243. https://doi.org/10.1093/mollus/ eyn011

CoOK L. M. 2017. Reflections on molluscan shell polymorphisms. Biological Journal of Linnean Society 121: 717-730. https://doi.org/10.1093/biolinnean/blx033

GHEOCA V. 2018. The first record of Cepaea nemoralis (Linnaeus, 1758) (Stylommatophora: Helicidae) from Romania. Acta Zoologica Bulgarica 70: 129-130.

Gheoca V., Benedek A. M., Cameron R. A. D., Stroia R. C. 2019. A century after introduction: variability in Cepaea hortensis (Müller, 1774) in Sibiu, central 
Romania. Journal of Molluscan Studies 85: 197-203. https://doi.org/10.1093/mollus/eyy064

JONES J. S., LeITH B. H., RAWLINGS P. 1977. Polymorphism in Cepaea: a problem with too many solutions? Annual Review and Systematics 8: 109-143. https://doi. org/10.1146/annurev.es.08.110177.000545

LINDSTRÖM G. 1868. Om Gotlands nutida mollusker. Inbjudan till bevistande af examina, premieutdelning och ungdomens hemförlofning vid Wisby Högre Elementar-Läroverk. Tryckt hos Th. Norrby, Wisby.

MALM A. W. 1851. Zoologiska observationer. $\$$ 8. Om Svenska Landt- och Söttvattens Mollusker, med särskilt afseende på de arter och former, som förekomma i grannskapet af Christianstad (C) och Götheborg (G). Göteborgs Kongliga Vetenskaps och Vitterhets Samhälles Handlingar N.F. 2: 111-131.

Örstan A., CAmeron R. A. D. 2015. Cepaea nemoralis in Burlington, New Jersey, USA: its possible origin and state 157 years after its introduction. Journal of Conchology 42: 193-196.

OżGO M. 2005. Cepaea nemoralis (L.) in southeastern Poland: association of morph frequencies with habitat. Journal of Molluscan. Studies 71: 93-103. https://doi. org/10.1093/mollus/eyi012

OżGO M. 2008. Current problems in the research of Cepaea polymorphism. Folia Malacologica 16: 55-60. https:// doi.org/10.12657/folmal.016.009

OżGo M. 2012. Shell polymorphism in the land-snail Cepaea nemoralis (L.) along a West-East transect in continental Europe. Folia Malacologica 20: 181-253. https://doi.org/10.2478/v10125-012-0015-1

OżGo M., CAMERON R. A. D., HORsáK M., POKRYSZKO B. M., Chudaś M., Cichy A., KaCZMAREK S., KOBAK J., MARZEC M., MIERZWA-SZYMKOWIAK D., PARZONKO D., PYKA G., ROSIN Z., SKAWINA A., SOROKA M., SULIKOWSKA-DROZD A., SUROWIEC T., SZYMANEK M., TEMPLIN J., URBAŃSKA M., ZAJĄC K., ZIELSKA J., ŻBIKOWSKA E., ŻOŁĄDEK J. 2019. Cepaea nemoralis (Gastropoda: Pulmonata) in Poland: patterns of variation in a range-expanding species. Biological Journal of Linnean Society 127: 1-11. https://doi.org/10.1093/ biolinnean/blz029

PELTANOVÁ A., DVOŘÁK L., JUŘIČKOVÁ L. 2012. The spread of non-native Cepaea nemoralis and Monacha cartusiana (Gastropoda: Pulmonata) in the Czech Republic with comments on other land snail immigrants. Biologia 67: 384-389. https://doi.org/10.2478/s11756-012-0020-2

POKRYSZKo B. M., CAMERON R. A. D., HorsáK M. 2012. Variation in the shell colour and banding polymorphism of Cepaea nemoralis (L.) in rural areas around Wrocław. Folia Malacologica 20: 87-98. https://doi.org/10.2478/ v10125-012-0012-4

PROSCHWITZ T. VON 2014. Landlevande mollusker. Snäckor och sniglar på Gotland. Natur på Gotland 30: 6-15.

ROSIN Z. M., OlBORSKA P., SURMACKI A., TRYJANOWSKI P. 2011. Differences in predatory pressure on terrestrial snails by birds and mammals. Journal of Bioscience 36 : 691-699. https://doi.org/10.1007/s12038-011-9077-2

Silvertown J., CoOK L. M., CAmeron R. A. D., DodD M., MCCONWAY K., WORTHINGTON J., SKELTON P., ANTON C., BOSSDORF O., BAUR B., SCHILTHUIZEN M., Fontaine B., SATTMANN H., BERTORELlE G., CORREIA M., Oliveira C., Pokryszko B., Ożgo M., Stalažs A., Gill E., RAmmul Ü., SÓlymos P., FÉHER Z., JUAN X. 2011. Citizen science reveals unexpected continental-scale evolutionary change in a model organism. PLoS ONE 6: e18927. https://doi.org/10.1371/journal. pone.0018927

SVERLOVA N. V. 2002. Vlijanie antropogennykh bar'erov na fenotipicheskuyu strukturu populacyi Cepaea hortensis (Gastropoda, Helicidae) v gorodskikh usloviakh. Vestnik Zoologii 36: 61-64.

WEIR B. S., COCKERHAM C. C. 1984. Estimating F-statistics for the analysis of population structure. Evolution 38: 1358-1370. https://doi.org/10.1111/j.1558-5646.1984. tb05657.x

Received: August 30th, 2019

Revised: October 20th, 2019

Accepted: October 24th, 2019

Published on-line: November 15th, 2019 
8 $10000000000000000000000-1000000000000$ ¿

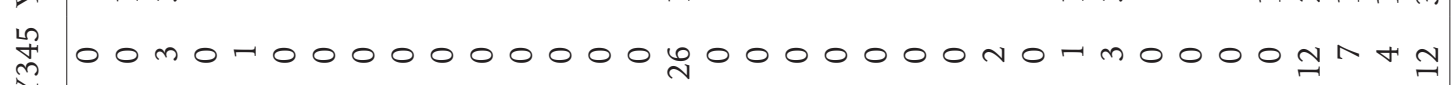

Z

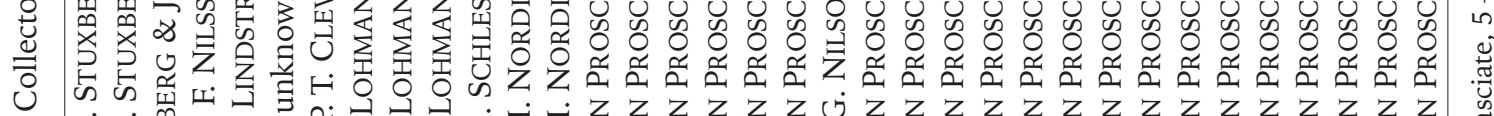

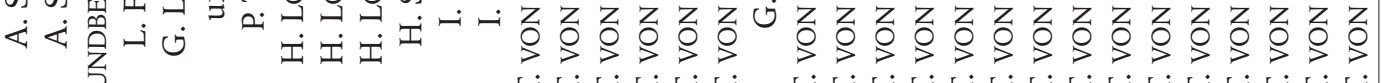
i

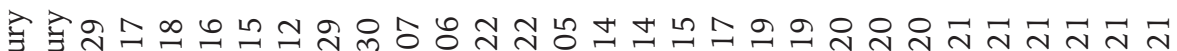
H HHHH H HHHHHHHHHHHHH

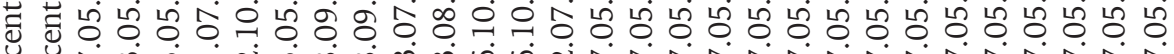

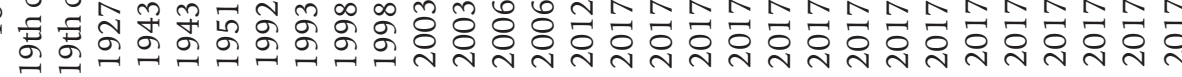

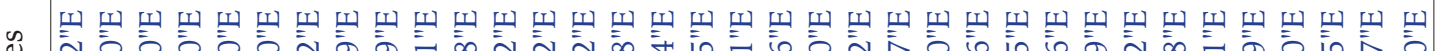

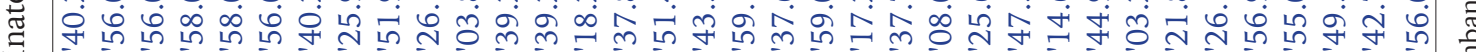
刍 字

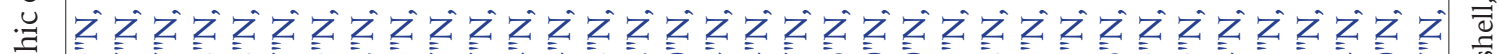
के অ.

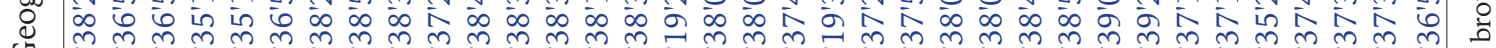

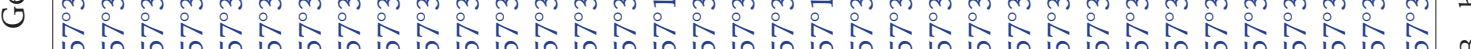

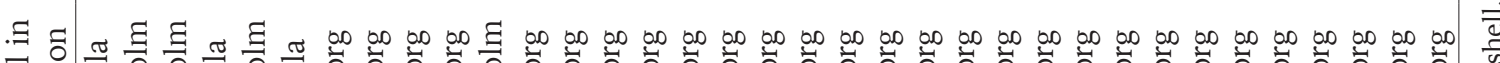

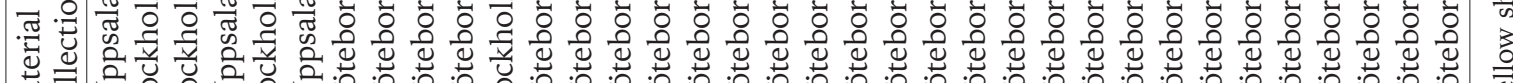

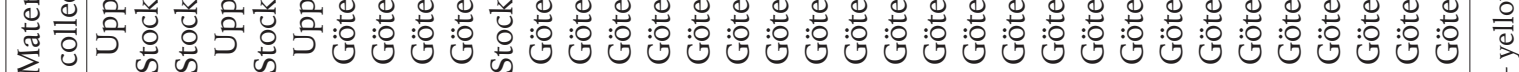
के

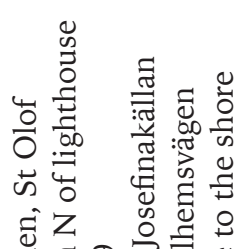

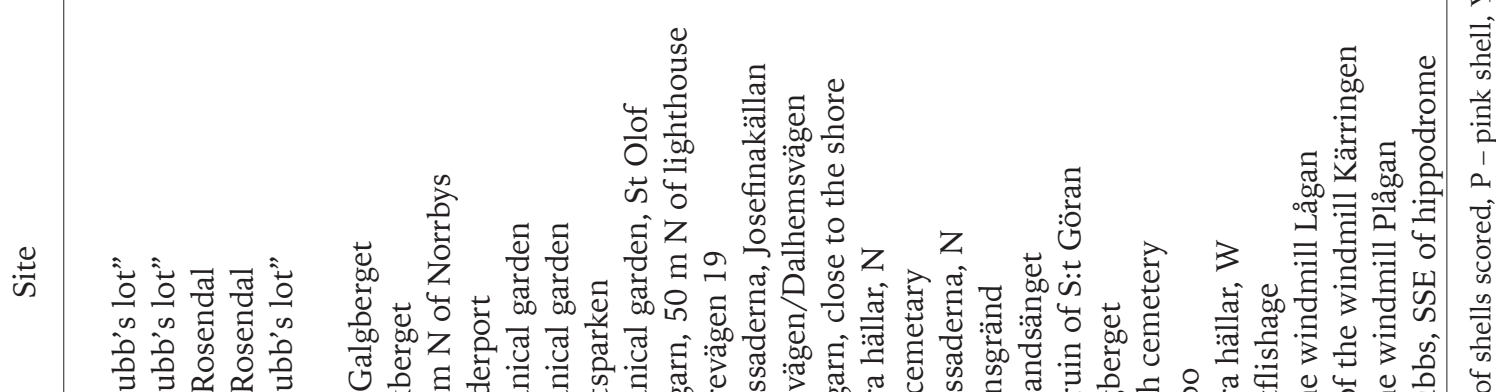

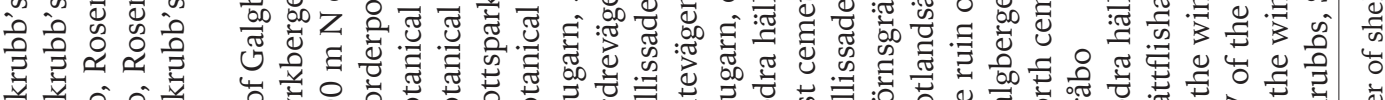

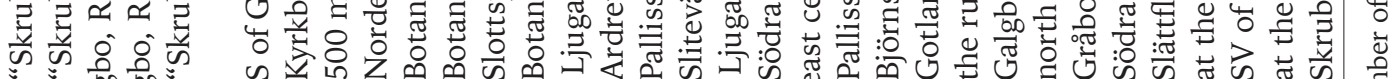

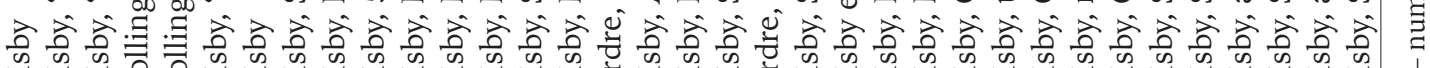

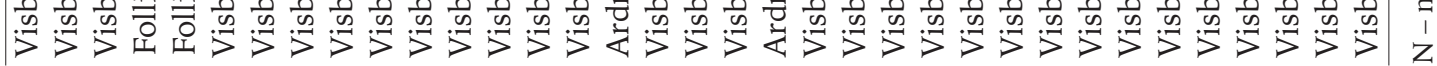

